\title{
THE FAMILY PRINCIPLE IN ECONOMY: UNDERSTANDING THE CONCEPT AND PRACTICAL CHALLENGE
}

\author{
Arjuna Rizaldi \\ Department of Management, Universitas Komputer Indonesia, Bandung, Indonesia
}

\begin{abstract}
This research aims to delineate how the family principle has been regarded and understood in Indonesia's Economy. Furthermore, it seeks to comprehensively understand the family principle to prevent further misconceptions or multi-interpretations. The method used is the qualitative approach that is based on literary studies. Besides providing the advantage of being exploratory in nature, the approach is suitable for studies in the environment of economic theory as researchers attempt to gain understanding through the thoughts and interpretation building of significant figures in the Indonesian economy. Overall, it is evident that cooperation and competition are the two crucial and equally important elements of the family principle to understand the concept comprehensively. Thus, the research concluded that both concepts had been integrated into the family principle as coopetition, whereas all economic institutions recognized by the constitution simultaneously compete and cooperate.
\end{abstract}

Keywords: Economy, Family Principle, Competition, Cooperation, Coopetition, SMEs, Cooperative.

DOI: http://dx.doi.org/10.15549/jeecar.v9i1.876

\section{INTRODUCTION}

The concept of family principle in the Indonesian economy was established since the proclamation of the republic. However, there are various interpretations of the concept of family principle, which led to various models of implementation that claim as the correct interpretation of family principle in the economy. Due to the partial understanding of the family principle and its aspects, the family principle is still left unclear; and the interpretations of how the family principle should be implemented as the fundamental pillar of the Indonesian economy are still ambiguous. It is a problem that needs further analysis. How can the family principle in the Indonesian economy be interpreted?
Not many studies specifically discuss the principle of kinship in economics. Previous research has discussed primarily the principle of kinship as part of a cooperative-based economy. Hatta has emphasized the concept of the family principle in the Indonesian economy. He imagined that the Indonesian people would unite together as a family to assemble the Indonesian economy. He stresses the importance of cooperation in the Indonesian economy since it is the only economic institution based on the family principle (Higgins, 1958). According to (Hermanto, 2018), the principle of kinship is part of economic democracy, namely the family economy or cooperatives. Thus, it can be seen that the principle of kinship is limited only in business entities in the form of 
cooperatives. However, cooperative interpretation as the sole interpretation of the family principle is insufficient since the Indonesian economy encompasses cooperative and another kind of business entity.

As the foundation of the Indonesian economy, the family principle has not been interpreted comprehensively. It is a common understanding that the family principle is the principle of cooperation. This collaboration aspect is considered good since it could ensure an equal distribution of welfare among all Indonesian people. The equal distribution of welfare has become an obsession of the founding fathers of Indonesia since both of them had experienced the colonial era where there was a wide economic gap in the society. This economic gap led to dissatisfaction among the majority of native Indonesian people. Therefore, the aspect of cooperation is considered a proper solution to eliminating the dissatisfaction of the Indonesian people.

In order to answer the question of how the family principle can be interpreted, it is necessary to understand how the founding fathers of Indonesia and prominent Indonesian economists viewed the Indonesian economic concept. However, the economic implementation often neglected the essential principles of the economy and therefore led the economy into chaos. Thus, a new economic idea arose to recover the economic condition. The new economists argue that economic development should be free from idealism and should entirely be based on the principle of economy. (Nitisastro, 2011) criticize the economy that was implemented irrationally and neglect the principle of the economy on behalf of the revolution.

They were rationalist and pragmatic economists and upheld an economic development based on efficiency, balance in the budget, and rational methodology based on a rational assumption and analysis. In the late 1970 s to 1980 s, some economists have observed the weakness of the economic concept only based on economic principles. They argue that this concept will lead the Indonesian economy to lean more towards capitalism, which in other words, will only benefit some groups of people. Prof. Dr. Emil Salim and Prof. Mubyarto later presented an economic concept to combine Indonesian socialism with economic principles. Through the concept of the Indonesian economy, they tried to combine the collective characters of Indonesian people with the principle of economy, especially competition (Mubyarto, 1987). Although the focus of the Indonesian economy is the micro, small, medium enterprise, and cooperative, the role of the state enterprise is not neglected. The state enterprise is expected to work coherently with the private enterprises and cooperative.

Meanwhile, the aspect of competition in the Indonesian economy could potentially cause a conflict among the society, disturbing the harmony among the Indonesian people. Moreover, it is considered a negative aspect as it is representative of capitalism. The competition aspect could also potentially develop into a "free fight liberalism" that would only profit some people. Thus, Indonesia's founding father emphasized cooperation in developing the economy to avoid conflict in society. Although, earlier economists such as Sumitro and Nitisastro had warned the government that cooperation could threaten the economic initiative and creativity of the people if it were to be misapplied.

Therefore, the novelty in this research aims to outline how to understand the family's principal concept in the Indonesian economy. It also aims to serve a comprehensive understanding of the family principle to prevent further misconceptions or multiinterpretations and multi-implementation.

The problem arose because the family principle, as the basis of the Indonesian economy, is insufficiently understood. This inadequate comprehension has, in turn, caused misconceptions and multiinterpretations of the Indonesian economy as a whole and as an economic system. The only necessary aspect is cooperation, whereas another significant aspect of the family principle, competition, is neglected. Thus, based on this argument, the hypothesis would be:

"Both cooperation and competition are equally important to obtain a comprehensive understanding of the family principle." 


\section{METHODOLOGY}

A qualitative method based on literary studies is used to provide a holistic approach to the family's principle in the Indonesian economy. In addition to being suitable for studies in economic theory, qualitative research has the advantage of being exploratory (Creswell, 2003). According to Creswell, researchers seek to listen to their respondents and build interpretations based on their ideas. Researchers "interact closely with those they study and minimize the distance between themselves to gather detailed and subjective information" (Creswell, 1994). Strauss \& Corbin (1990) stated that qualitative research produced findings not arrived at through statistical procedures or other means of quantification.

This qualitative research will seek out the reason and not the process of its topic by analyzing unstructured information. Imms \& Ereaut (2013). The focal points of this research are shown in figure 1.

The focal points of qualitative research in this study are as follows:

- What People Say. It consists of the common knowledge of the people on the research topic and what they understand.

- Mean, need or desire. It consists of emotional drivers both consciously and unconsciously. It also related to the psyche on the topic.

- What people do. It consists on the action and what they see themselves doing, as well as researching any meaningful behavior.

- Culture. It related to cultural forces and meaning system and its correlation to the topic of the research, as well as researching shared, meaning, norms and/or codes.

Therefore, the aim of the qualitative research is to gain an understanding related to the research topic.

Therefore, in this research, the literature analysis method is used to excavate and analyze the family principle in the Indonesian economy and its relevant implementation. Since the data is obtained through scholarly publications, the inductive approach is appropriate for this study. The inductive approach will be conducted based on analyzing ideas from the founding fathers of Indonesia and from various Indonesian economists to find out the similarities of ideas of the family principle.

Thus, the Document analysis method is used in this research. This method is also known as the historical method. It is an indirect social research method in which literature is reviewed and collected to analyze and studyrelated social phenomena (Miao, 2019).

Also, content analysis is used in this research. According to (Sukardi, 2012) it is research-based on an in-depth discussion of the contents on written or printed information. The definition above is clear that Content Analysis is a method that includes all analysis of the content of the text. Still, on the other hand, Content Analysis is also used to describe a specific analytical approach. Content Analysis is a way to conclude by identifying the various unique characteristics objectively, systematically, and in a generalist manner.

This research is descriptive. The explanatory research has a pattern of observations with a specific time. (Airasian \& Gay, 2012) defines descriptive research methods as activities that include collecting data to test hypotheses or answer questions concerning the current state of the subject of a study. While (Singarimbun \& Effendi, 1989) explain descriptive method research as research intended to carry out careful measurements of a particular phenomenon by developing concepts and collecting facts contained within the company or outside but does not perform a hypothesis test.

This research has several limitations. The most significant one is that the author only analyses the interpretation of the family principle in the Indonesian economy and how it has been implemented so far based on a sole observation. Thus, the author has to limit himself from proposing alternatives in technical, economic fields. It is also necessary to limit only an analyzer, not a performer.

Furthermore, the time provided for this research project is limited. The time limitation affects the depth of the analysis and the completeness of aspects in Pancasila Economic and family principles alike. Thus, the limited research time also affects the number of scholarly publications being referred to. It may affect the author's perspective on measuring several essential things to understand the 
problems comprehensively. Aside from that, the author is also aware of any potential biases during the analysis. However, the author will try to consider as many aspects as possible.

\section{RESULTS}

The constitutional foundation of the Indonesian economy can be found in the 1945 Constitution, especially in articles 27,33 , and 34. By implementing the concept of the Indonesian economy, every citizen is guaranteed to have a job and good life based on humanity. Moreover, the state is responsible for the poor people by implementing a national social security system.

Meanwhile, the form of the Indonesian economy is stated in article 33 paragraphs 1, 2, and 3 , as follows:

\section{Paragraph 1}

"The economy shall be organized as a common endeavor based upon the family principles."

\section{Paragraph 2}

"The sectors of production which are important for the country and affect the life of the people shall be under the powers of the State."

\section{Paragraph 3}

"The land, the waters and the natural resources within shall be under the power of the State and shall be used to the greatest benefit of the people."

It is common knowledge that these three paragraphs are consecutively interpreted as the constitutional foundation of cooperative, the state enterprise, and the private company. Even so, when we look deeper into the statements above, both Emil Salim and Mubyarto never clearly explained such interpretation (Mubyarto, 1987:179). It cannot be found either in the explanation of the 1945 Constitution published by the General Secretariat of the People's Consultative Assembly. Overall, it cannot be concluded that article 33, paragraphs 1,2 , and 3 consecutively are the constitutional foundation of cooperative, the state enterprise, and the private company.

The family principle in cooperative is defined as norms of group action and mutual help. Group action means that all policies and activities must be based on mutual interest. Meanwhile, mutual help means that every activity in cooperative must involve participation from the committees, supervisors, and all members. Thus, it forms the aspect of democracy in cooperation. (Hatta, 1992). Cooperative is the only economic institution based on the family principle.

Furthermore, it is stated that cooperative also functions to shorten the distribution line and thus lower the price of goods sold. In addition, all cooperative members will benefit in the form of remaining interest at the end of a fiscal year. Furthermore, there was a doubt whether an economic system is entirely based on a cooperative approach can be realized. (Soesatro (ed.), 2005). Therefore, cooperative is considered more profitable for people with low purchasing power.

Also, integrating the cooperative with the micro, small and medium enterprises can function as a "bridge" to provide external finance for their development. The principle of education in cooperative functions is not only to educate the members and the management of the cooperative but also to educate the society, the micro, small and medium enterprise and develop themselves by giving the possibility to secure the external financing that they often lack.

As for the state-owned company, according to Law No.9/1969 on the form of the state enterprises, there are three types of state enterprise in Indonesia:

1). Service Company, the government owns all the shares. Not a profit-oriented company. It exists to provide service to the people.

2). Public Company: similarly to Service Company, the government owns all the shares. However, the purpose of a Perum is divided equally between providing service and making a profit.

3). Limited Liabilities Company: the government owns all the shares or at least the majority.

The last pillar in the Indonesian economy is the private company. There are four types of private companies existing in Indonesia. There are

1). Sole Proprietorship, owned by one person. The owner usually operates the business personally. There is no distinction between personal wealth and the wealth of the company. The owner takes full responsibility for the company 
and has full responsibility without legal documents and official establishment time. If two persons or more are joined together, it is considered Civil Federation as regulated in the Indonesian Civil article 1618-1652. 2).

2). Firma, established by two persons or more. Each plays an active role in the company and has full responsibility. According to the Indonesian Commercial Code article 16 , a firm is a civil partnership to run a company with a joint name.

3). Comanditaire Venootshcap (CV), established by two persons or more, plays an active role in the company, and some play a passive role. The member who plays an active role in the company has full responsibility, while the passive member has limited responsibility. It is regulated in articles 19, 20, and 21 of the Indonesian Commercial Code. And

4). Limited Company (LC), a business entity whose capital is based on a share. The shareowner (shareholders/stockholders) will profit in dividends at the end of a yearbook. The difference between the private $\mathrm{LC}$ and the government $\mathrm{LC}$ is that in the government LC, all the shares, or at least the majority, are owned by the government. The definition of LC is a conclusion based on articles $36,40,42$, and 45 of the Indonesian Commercial Code. (Purwosutjipto, 2005).

It is a common understanding that a company is identical to a professional company with its organizational structure and positions, while most Sole Proprietorship does not have such things. It can be concluded that there are at least two misinterpretations of how the family principle is implemented. Firstly, the misinterpretation in understanding article 33 of the 1945 Constitution points 1,2 , and 3 is considered the constitutional foundation of the cooperative, the state enterprises, and the private companies. The second misinterpretation is that paragraph 1 of article 33 is addressed only for cooperation. This interpretation is based on Hatta's statement that cooperative is the most concrete economic institution based on the family principle. Thus, paragraph 1 is considered identical with cooperative (Higgins, 1958).
The aspects of cooperation and competition in relation with the family are principles. The family principle is the principle of cooperation. This aspect of cooperation is considered good since it could ensure an equal distribution of welfare among all Indonesian people. However, both Salim and Mubyarto aim to seek a balance between cooperation and competition. Mubyarto argued that competition is already becoming a part of the family principle, and thus, it should be acknowledged. However, Mubyarto also argued that the aspect of competition should be kept as healthy as possible and maintained well so it would not turn into a "free-fight competition. The most important thing is, however, to gain a comprehensive understanding of the family principle, both aspects of cooperation and competition should be equally acknowledged. Both aspects should not be applied alternately but simultaneously.

However, the latest development is the aspect of competition and cooperation are not alternately applied. It is apparent that in practice, the business institution can compete and cooperate at the same time simultaneously. Thus, the concept of family principle in the Indonesian economy concentrates on three business institutions; cooperatives, state enterprises, and private companies, and aims to seek an equilibrium between them.

The concept of competition could be extended into a coopetition relationship in the frame of the family principle. Thus, it could become a basis of the relationship between cooperative, the state enterprise, and the private company to achieve its goal of improving public welfare (Walley, 2007). Therefore, all pillars in the Indonesian economy may cooperate in developing different sectors while competing against each other to be the most profitable and provide the best service to the people. However, this scheme would not work until both aspects of competition are fully acknowledged and play an essential role in the Indonesian economy, especially in the driving force for economic activity to increase the productivity of a business institution.

Both aspects of cooperation and competition contain positive and negative effects. The aspect of collaboration could perhaps ensure 
the distribution of goods and services to all Indonesian people and thus, preserve a harmonious life. However, it could also turn into collusion that ruins the dynamic of the economic atmosphere and eventually only benefits some groups of people.

Meanwhile, the aspect of competition has an excellent probability of turning into a free-fight competition that harms the interest of most people and, therefore, creates a conflict that ruins harmony. Nevertheless, competition could increase economic innovation and lower the price.

Therefore, it can be concluded that both aspects of cooperation and competition should be equally acknowledged to gain a comprehensive understanding of the family principle as the basis of Pancasila Economic. However, it is unlikely that cooperation and competition will be applied alternately. Both aspects are at the same time simultaneously applied. Thus, the business institutions are applying both aspects at the same time simultaneously. This new development is called coopetition.

The term used to refer to this combination of simultaneous competition and coopetition is coopetition. The origin of this term is unclear. However, it is commonly accepted that the term was first used in the 1980s by Ray Noorda, the founder, and CEO of Novell. (Walley, 2007).

The author argues that the Indonesian economists have provided several indications that confirm the view of competition. Widjojo (Wie 2012) argued that cooperatives and private companies should be given specific sectors to operate.

Cooperates could operate in essential sectors and affect the people's lives with support from the state's enterprises. On the other hand, private companies could engage in less important sectors. Meanwhile, Sumitro argued that the government should give private companies some space in the economy and limit its supervision and intervention only on the most crucial economic matters. It was also necessary for the government to engage in the most vital sectors so that the principle of social progress can be ensured and the economic initiative and creativity of the people can continuously be stimulated. (Soesatro (ed.), 2005).

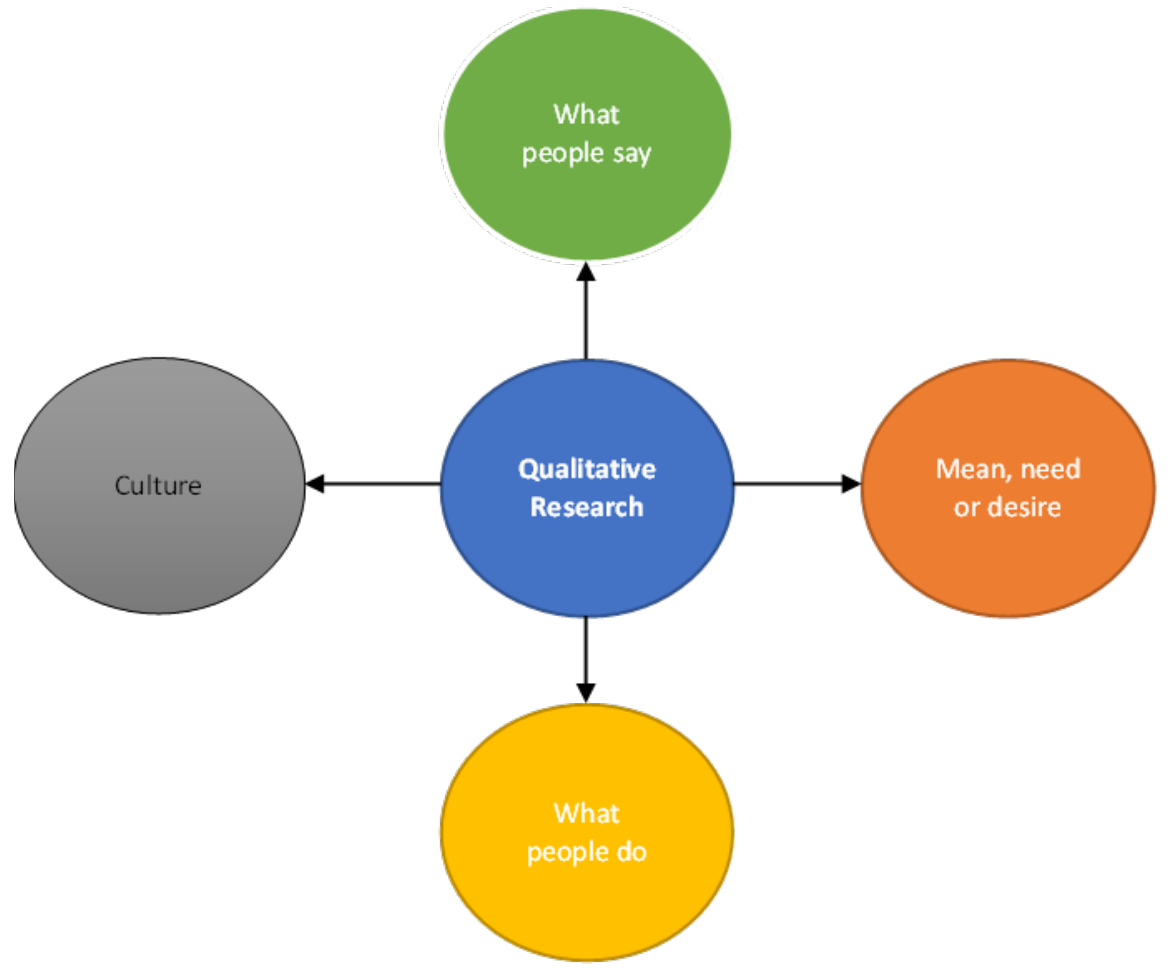

Figure 1: Focal Points of Qualitative Research

Source: Author's work 


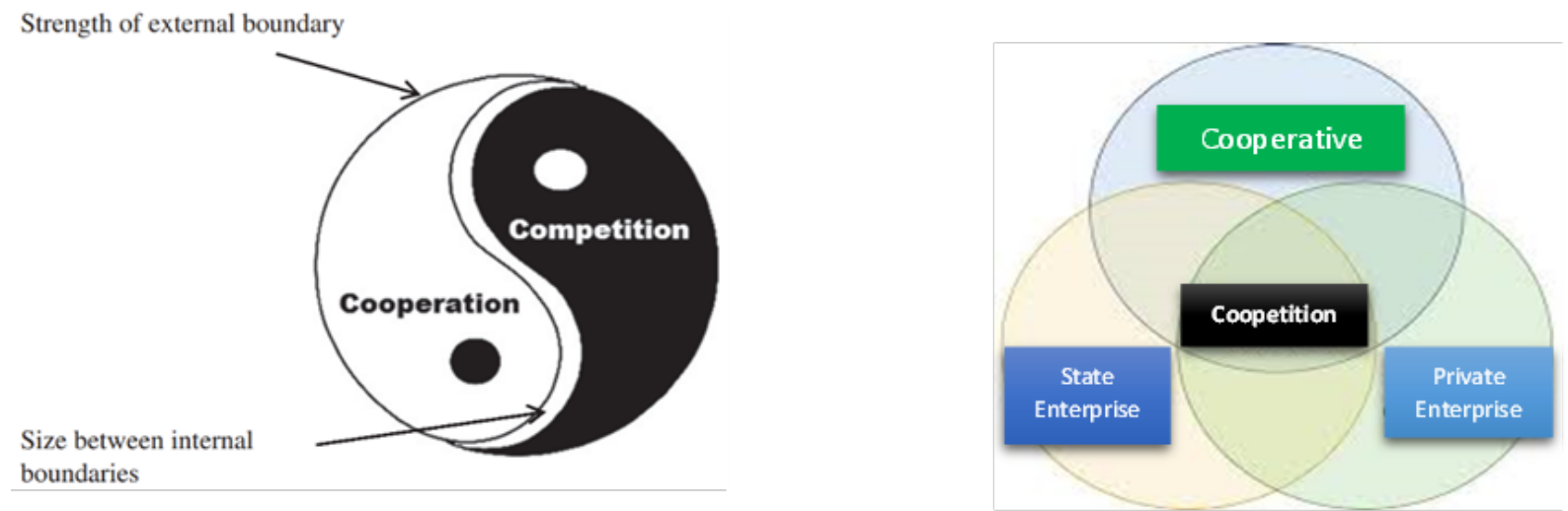

Figure 2: Coopetitive relation proposed by Raza-Ullah, (Bengtsson \& Kock, 2014) (Left) and Coopetitive relation proposed in this research (right)

The term coopetition is understood as an effort to examine the relationship pattern between firms. However, Walley (2007) argued that it is necessary to extend the conceptual domain of coopetition. Therefore, it is also possible to understand the pattern of relationship between the pillars of the Indonesian economy by using the concept of coopetition. However, it requires more profound research on the role of each business institution (cooperative, state enterprise, and private company) by the laws and the priorities of economic development.

The most important thing is, however, to gain a comprehensive understanding of the family principle, both aspects of cooperation and competition should be equally acknowledged, and both aspects should not be applied alternately but simultaneously. Previous research proposed a coopetition model based on the strength of external boundary and size between internal boundary as seen in figure 2 . (Raza-Ullah, Bengtsson \& Kock, 2014).

\section{DISCUSSION AND CONCLUSION}

To answer the question posed in the opening chapter: "How can the family principle in the Indonesian economy be interpreted?" the author developed the hypothesis that "Both, cooperation and competition are equally important in obtaining a comprehensive understanding of the family principle." The author's analysis of the family principle confirmed this hypothesis. The findings indicate that cooperation and competition are the two crucial elements of the family principle. However, the author argues that the degree to which these two elements interplay varies.
Looking at how different generations have approached and implemented the family principle, it becomes clear that the earlier generation emphasized cooperation. In contrast, leading authorities propose a rational and pragmatic economic concept now. However, both concepts have been integrated into the Indonesian economy.

This view, however, does not have any substantial evidence. In fact, to a certain degree, all figures discussed in this study indicate that competition exists and should also be encouraged to achieve balance. Moreover, the family principle invigorates the economic process. However, it should be emphasized that cooperation and competition do not apply alternately. Instead, both aspects are applied at the same time. Thus, in answering the previous question, the author concludes that the family principle in the economy is an economic concept that includes both cooperation and competition to foster healthy and dynamic economic development.

Further studies should discuss how the coopetition mechanism works in an economic process between three business institutions in Indonesia. Future research should analyze cooperatives and their legal framework, such as laws, Presidential Decrees, etc.) to understand how cooperatives function in the business sector. Such a study would expose the boundaries of the cooperative movement, and it could investigate a variety of ways that might improve the role of cooperatives in the Indonesian national economy. 


\section{REFERENCES}

Airasian, P.W, Mills, G. \& Gay, L.R. (2012). Educational research: Competencies for analysis and application. USA: Pearson Education, Inc.

Bengtsson, Maria, Jessika Eriksson \& Joakim Wincent. (2010). Coopetition dynamics An Outline for Further Inquiry. Competitiveness Review: An International Business Journal, Vol. 20(2). pp. 194-214. Doi: 10.1108/10595421011029893

Bouncken, R. B., Fredrich, V., \& Kraus, S. (2019). Configurations of firm-level value capture in coopetition. Long Range Planning. doi:10.1016/j.lrp.2019.02.002

Christ, K. L., Burritt, R. L., \& Varsei, M. (2017). Coopetition as a Potential Strategy for Corporate Sustainability. Business Strategy and the Environment, 26(7), 1029-1040. doi:10.1002/bse.1967

Creswell, J. W. (1994). Research design: Qualitative and quantitative approaches. Thousand Oaks, CA: SAGE Publications.

Creswell, J.W. (2003). Research design: Qualitative, quantitative, and mixed methods approaches. (2nd ed.) Thousand Oaks: Sage

Czakon, W., Klimas, P., \& Mariani, M. (2020). Behavioral antecedents of coopetition: A synthesis and measurement scale. Long Range Planning, 53(1), 101875. doi:10.1016/j.lrp.2019.03.001

De Soto, Hernando, The Mystery of Capital Rahasia Kejayaan Kapitalisme Barat, Qalam, Yogyakarta, 2006

Hermanto, Asep Bambang. (2018) Politik Hukum dalam Demokrasi Ekonomi Indonesia. Jurnal Selisik 4(1) (2018): Juni p: 4-28

Higgins, Benjamin. (1958). Hatta and Cooperatives: The Middle Way for Indonesia?, Center for International Studies of the Massachusetts Institute of Technology, Massachusetts, 1958

Imms, M. \& Ereaut, Gill. (2013). An introduction to qualitative market research. 10.4135/9781849208550.

Limbong, Bernhard, Ekonomi Kerakyatan dan Nasionalisme Ekonomi, Margaretha Pustaka, Jakarta, 2013.
Miao, Z. (2019), "Investigation on human rights ethics in artificial intelligence researches with library literature analysis method", The Electronic Library, 375), pp. 914-926. https://doi.org/10.1108/EL-042019-0089

Mubyarto, Indonesian economy (Gagasan dan Kemungkinan), LP3ES, Jakarta, 1987

Nitisastro, W., ISEAS, The Indonesian Development Experience (A Collection of Writings and Speeches of Widjojo Nitisastro), ISEAS Publishing, Singapore, 2011

Singarimbun, Masri dan Sofian Effendi. 1989. Metode Penelitian Survei. Jakarta. LP3ES

Soesatro, Hadi (ed.), ISEI, Pemikiran dan Permasalahan Ekonomi di Indonesia dalam Setengah Abad Terakhir (Buku 1, 1945-1959, Membangun Ekonomi Nasional), Kanisius, Yogyakarta, 2005

Soesatro, Hadi (ed.), ISEI, Pemikiran dan Permasalahan Ekonomi di Indonesia dalam Setengah Abad Terakhir (Buku 2, 1959-1966, Ekonomi Terpimpin), Kanisius, Yogyakarta, 2005

Soesatro, Hadi (ed.), ISEI, Pemikiran dan Permasalahan Ekonomi di Indonesia dalam Setengah Abad Terakhir (Buku 3, 1966-1982, Paruh Pertama Ekonomi Orde Baru), Kanisius, Yogyakarta, 2005

Soesatro, Hadi (ed.), ISEI, Pemikiran dan Permasalahan Ekonomi di Indonesia dalam Setengah Abad Terakhir (Buku 4, 1992-1997, Deregulasi dan Liberalisasi Ekonomi), Kanisius, Yogyakarta, 2005

Soesatro, Hadi (ed.), ISEI, Pemikiran dan Permasalahan Ekonomi di Indonesia dalam Setengah Abad Terakhir (Buku 5, 1997-2005, Krisis dan Pemulihan Ekonomi), Kanisius, Yogyakarta, 2005

Subandi, DR, M.M., Ekonomi Koperasi (Teori dan Praktik), Alfabeta, Bandung, 2013

Sukardi (2012). Metodologi Penelitian Pendidikan. Jakarta: Bumi Aksara

Swasono, Sri-Edi \& Ridjal F., Mohammad Hatta, Beberapa Pokok Pikiran, UI-Press, Jakarta, 1992

Swasono, Sri-Edi, Prof. Dr., Pembangunan Berwawasan Sejarah: Kedaulatan Rakyat, Demokrasi Ekonomi, dan Demokrasi Politik, UI Press, Jakarta, 1990 
Undang-undang (UU) No. 09 Tahun 1969 Tentang Bentuk-bentuk Badan Usaha Negara

Undang-undang (UU) No. 25 Tahun 1992 Tentang Koperasi

Walley, Keith. (2007). Coopetition: An Introduction to the Subject and an Agenda for Research. International Studies of Management \& Organization, 372), 11-31. Doi: 10.2753/IMO0020-8825370201

Wie, Thee Kian, Indonesia's Economy since Independence, ISEAS Publishing, Singapore 2012

Zhu, Y., Lynette Wang, V., Wang, Y.J. and Nastos, J. (2020), "Business-to-business referral as digital coopetition strategy: Insights from an industry-wise digital business network", European Journal of Marketing, 54(6), pp. 1181-1203. https://doi.org/10.1108/EJM-01-20190011.

\section{ABOUT THE AUTHOR}

Arjuna Rizaldi, email: arjuna@email.unikom.ac.id

Arjuna Rizaldi, M.A. in International M.A. Program Language and Cultures of Southeast Asia, Universität Hamburg, Freie und Hansestad Hamburg, Germany. Lecturer of the Department of Marketing Management, Universitas Komputer Indonesia, Bandung, Indonesia 